\title{
BIOREPRODUKSI DAN HUBUNGAN PANJANG-BOBOT TERHADAP FEKUNDITAS PADA IKAN LALAWAK (Barbonymus balleroides)
}

\author{
Irin Iriana Kusmini", Fera Permata Putri, dan Vitas Atmadi Prakoso \\ Balai Penelitian dan Pengembangan Budidaya Air Tawar
}

\begin{abstract}
ABSTRAK
Eksploitasi ikan lalawak (Barbonymus balleroides) yang berlebihan dari alam mengakibatkan langkanya jenis ikan ini di beberapa perairan aslinya. Sebelum ikan ini diperkenalkan sebagai komoditas budidaya, masih diperlukan lebih banyak lagi informasi mengenai aspek bioreproduksi ikan lalawak yang telah dipelihara pada lingkungan budidaya. Tujuan dari kegiatan ini adalah untuk mengevaluasi produktivitas ikan lalawak yang dipelihara pada lingkungan budidaya melalui pengamatan bioreproduksi dan hubungan panjangbobot terhadap fekunditas. Sampel induk ikan lalawak betina yang diambil sebanyak 15 ekor, kemudian dipilih lima ekor induk betina yang telah matang gonad dengan ciri-ciri seluruh badannya terasa kasar apabila diraba, perut membesar ke arah posterior dan terasa lunak, genital mengembang, serta berwarna kemerahan. Data yang dikoleksi berupa panjang total, bobot badan, bobot gonad, fekunditas, diameter telur, dan indeks kematangan gonadnya. Hasil penelitian menunjukkan bahwa kisaran fekunditas ikan lalawak adalah 1.920-2.236 butir/g bobot gonad, dan 83-352 butir/g bobot badan induk dengan rata-rata diameter telur 0,87-1,10 mm. IKG berkisar 3,73\%18,36\%dari kisaran bobot induk 85,32-264,8 g. Hubungan antara bobot badan dengan bobot gonad ikan lalawak digambarkan dengan persamaan linear $y=5,829 \mathrm{ln}$ $(x)+0,691(r=0,874)$; sedangkan hubungan panjang badan terhadap bobot gonad digambarkan dengan persamaan $\mathrm{y}=28,52 \ln (\mathrm{x})-38,10(\mathrm{r}=0,7487)$. Pada ikan lalawak, hubungan bobot badan dengan fekunditas lebih erat dibandingkan dengan hubungan panjang badan terhadap fekunditas. Hasil pengamatan juga menyimpulkan bahwa ikan lalawak tergolong ikan yang memijah secara parsial.
\end{abstract}

\section{KATA KUNCI: ikan Ialawak; Barbonymus balleroides; bioreproduksi; IKG; fekunditas}

ABSTRACT: Reproductive biology and length-weight relationship on fecundity of lalawak (Barbonymus balleroides). By: Irin Iriana Kusmini, Fera Permata Putri, and Vitas Atmadi Prakoso

Over-exploitation of lalawak (Barbonymus balleroides) from its natural habitat had significant negative impacts on its availability. Before it is introduced as aquaculture commodity, more information about its reproductive biology in aquaculture environment needs to be well observed. The aim of this study was to determine the productivity of lalawak reared in aquaculture environment through observation of bioreproduction and relationship between fecundity and body length-weight of lalawak. Sample was randomly taken from fifteen individuals female. From those samples, gonads were taken from five mature females for reproduction observation, by which the mature females were selected following specific criteria such as : their body feels rough if touched; enlarged abdomen posteriorly and felt soft; fluffy and reddish genital. Data collection consisted of measurement of the total length, body weight, gonad weight, fecundity, egg diameter and gonadosomatic index (GSI). The results revealed that the fecundity of lalawak ranged from 1,920 to 2,236 eggs/g of gonad weight and 83 to $352 \mathrm{eggs} / \mathrm{g}$ of body weight with average diameters of eg gs ranged from 0.869 to $1.10 \mathrm{~mm}$. GSI values ranged from 3.73 to $18.36 \%$ of 85.32 to $264.8 \mathrm{~g}$ of body weight. The relationship between body weight and gonad weight of lalawak was described by the linear equation of $y=5,829 \mathrm{ln}$ $(x)+0.691(r=0.874)$, while the body length relationship to the gonad weight was described by the equation of $y=28,52 \ln (x)-38.10(r=0.7487)$. Fecundity relationship with body weight of lalawak was closer than the length. The observations also concluded that lalawak is classified as partial spawner.

KEYWORDS: lalawak; Barbonymus balleroides; reproductive biology; gonadosomatic index; fecundity

\footnotetext{
\# Korespondensi: Balai Penelitian dan Pengembangan Budidaya

Air Tawar. Jl. Sempur No. 1 Bogor 16154, Indonesia.

Tel. + (0251) 8313200

E-mail: iriniriana@gmail.com
} 


\section{PENDAHULUAN}

Ikan lalawak (Barbonymus balleroides) termasuk ke dalam Famili Cyprinidae sama halnya dengan ikan tengadak (Barbonymus schwanenfeldii). Ikan lalawak ada tiga jenis, yaitu ikan lalawak jengkol, lalawak sungai, dan lalawak kolam (Yulfiperius et al., 2004). Jika diperhatikan cara makannya (feeding habit), ikan lalawak tampak lebih rakus dan lebih agresif terhadap makanan yang diberikan. Habitat ikan lalawak adalah perairan tawar seperti danau, sungai, dan rawa. Ikan ini memiliki potensi yang cukup besar untuk dibudidayakan sebagai ikan konsumsi, karena ikan ini dapat tumbuh lebih besar dibandingkan ikan nilem. Selain itu, ikan lalawak dapat juga dijadikan sebagai ikan hias karena warna sisik yang mengkilap dan sirip yang bagus. Ikan Ialawak sampai saat ini masih berstatus sebagai ikan liar meskipun sudah ada yang berupaya untuk membudidayakan dan memelihara di kolam. Akan tetapi, sebagian besar masih diperoleh dari hasil penangkapan di alam. Keberadaan ikan ini di beberapa daerah hampir punah. Kepunahan ikan diduga akibat tingginya tingkat pencemaran di habitat aslinya, penurunan kualitas air, menurunnya debit air terutama pada musim kemarau, serta penangkapan yang berlebihan (Yulfiperius et al., 2004; Alavi et al., 2009).

Mengingat strategi industrialisasi perikanan budidaya Kementerian Kelautan dan Perikanan (KKP) tidak hanya berpedoman pada peluang ekspor tetapi lebih pada upaya untuk menciptakan pertumbuhan ekonomi, dan pemerataan pendapatan bagi masyarakat perikanan. Dengan demikian ikan lalawak dapat dijadikan salah satu kandidat ikan budidaya di samping untuk meningkatkan pertumbuhan ekonomi di sektor perikanan, sekaligus dapat menjaga kelestarian ikan lalawak di alam. Usaha pembudidayaan ikan alamiah dapat dilakukan dengan baik jika sifat-sifat biologi ikan diketahui dengan sebaik-baiknya, di antaranya adalah aspek bioreproduksi dan hubungan panjangbobot. Reproduksi merupakan tahapan penting dalam siklus hidupnya untuk menjamin kelangsungan hidup suatu spesies (Effendie, 2002). Setiap jenis ikan memiliki perbedaan pada aspek bioreproduksi maupun hubungan panjang-bobotnya. Contohnya yaitu fekunditas ikan lampam (Barbonymus schwanenfeldii) yang berkisar antara 1.393-7.826 butir dan rata-rata fekunditas per ekor ikan adalah 5.096 butir telur. Kisaran nilai IKG ikan lampam betina lebih besar $(0,863 \% 9,347 \%)$ daripada ikan jantan $(0,506 \% 2,826 \%)$ (Setiawan, 2007). Ikan belanak (Mugil dussumieri) di Ujung Pangkah, Jawa Timur mempunyai hubungan panjang-bobot dengan nilai $\mathrm{R}^{2} 0,966(96,6 \%)$ untuk jantan dan betina 0,9673 $(96,7 \%$ (Sulistiono et al., 2001). Sementara itu, hubungan panjang-bobot ikan
Liza subviridis di perairan Taman Nasional Ujung Kulon menunjukkan nilai koefisien korelasi ( $r$ ) untuk jantan yaitu 0,985 ; dan betina 0,978 (Wahyudewantoro \& Haryono, 2013).

Menurut Luvi (2000), nilai IKG ikan lalawak yang tertangkap di Sungai Cimanuk untuk yang jantan berkisar antara 0,78\%sampai 6,26\%sedangkan yang betina 0,71\%sampai 29,07\% Menurut Effendie (2002), setiap spesies ikan dan bahkan pada spesies yang sama tidak memiliki kesamaan awal matang gonadnya, hal ini dapat disebabkan perbedaan wilayah penyebaran dan banyaknya makanan. Berdasarkan penelitian terdahulu, ikan lalawak jengkol mempunyai kemampuan reproduksi yang cukup baik jika dibandingkan dengan ikan lalawak sungai dan kolam (Yulfiperius et al., 2004).

Meskipun beberapa penelitian tentang ikan lalawak telah dilakukan, masih diperlukan lebih banyak lagi informasi mengenai ikan lalawak ini untuk dapat dijadikan komoditas budidaya. Oleh karena itu, penelitian ini dilakukan untuk mendapatkan informasi bioreproduksi dan hubungan fekunditas terhadap panjang-bobot pada ikan lalawak yang dipelihara pada lingkungan budidaya.

\section{BAHAN DAN METODE}

Objek penelitian dalam kegiatan ini adalah ikan lalawak. Berdasarkan referensi dari Yulfiperius et al. (2004), ikan yang digunakan dalam penelitian ini merupakan jenis ikan lalawak kolam. Sampel ikan merupakan ikan yang telah beradaptasi pada lingkungan budidaya dari Waduk Cirata, Cianjur, Jawa Barat yang diambil pada bulan September 2015. Sampel induk ikan betina diambil secara acak sebanyak 15 ekor dari 60 ekor betina. Selanjutnya untuk mengetahui reproduksi ikan lalawak, dilakukan pembedahan ikan betina yang telah mengalami perkembangan gonad sebanyak lima ekor dengan ciriciri induk matang gonad yaitu seluruh badannya memiliki sisik yang terasa kasar apabila diraba, perut membesar ke arah posterior dan terasa lunak, serta genital mengembang dan berwarna kemerahan. Koleksi data dilakukan di Instalasi Penelitian Plasma Nutfah Perikanan Air Tawar, Cijeruk-Bogor, Jawa Barat. Pengambilan data meliputi pengukuran panjang total, bobot badan ikan, bobot gonad, fekunditas, dan diameter telur. Pengukuran diameter telur dilakukan dengan menggunakan mikroskop yang dilengkapi mikrometer okuler pada pembesaran 4 × 10 . Pengamatan tingkat kematangan gonad induk ikan lalawak mengacu pada penelitian terdahulu yang dilakukan pada ikan yang masih satu famili, yaitu Barbonymus schwanenfeldii (Tabel 1). 
Tabel 1. Tingkat kematangan gonad ikan kapiek (Barbonymus schwanenfeldii Bleeker) (Siregar, 1991) Tablel. The maturity level of gonads tinfoil barb (Barbonymus schwanenfeldii Bleeker) (Siregar, 1991)

\begin{tabular}{|c|c|c|c|}
\hline $\begin{array}{c}\text { TKG } \\
\text { Gonad } \\
\text { maturity level }\end{array}$ & $\begin{array}{l}\text { Tahapan } \\
\text { Stage }\end{array}$ & Visual (Nisual) & $\begin{array}{l}\text { Mikroskopis } \\
\text { Microscopic }\end{array}$ \\
\hline 1 & $\begin{array}{l}\text { Belum matang } \\
\text { Immature }\end{array}$ & $\begin{array}{l}\text { Ovari kecil dan testis } 1 / 3 \text { dari rongga } \\
\text { badan, bentuk telur oval. } \\
\text { Warna ovari merah muda, transparan } \\
\text { Ovary was small and testicular was about } \\
1 / 3 \text { from the body cavity, oval-shaped egg. } \\
\text { pink coloring, transparent }\end{array}$ & $\begin{array}{l}\text { Telur kecil, tidak nampak oleh mata } \\
\text { telanjang, diameter } 1-16 \mu \mathrm{m}, \\
\text { transparan } \\
\text { Small eggs, invisible with naked eye } \\
\text { (diameter: 1-16 } \mu \mathrm{m} \text { ), transparent }\end{array}$ \\
\hline II & $\begin{array}{l}\text { Pematangan } \\
\text { Maturing }\end{array}$ & $\begin{array}{l}\text { Ovari kecil, warna ovari merah muda, } \\
\text { transparan } \\
\text { Ovary was small, pink coloring, } \\
\text { transparent }\end{array}$ & $\begin{array}{c}\text { Telur tidak tampak oleh mata } \\
\text { telanjang, telur jernih, } \\
\text { ukuran diameter } 10-21 \mu \mathrm{m} \\
\text { Eggs were invisible with naked eye } \\
\text { (diameter: } 10-21 \mu \mathrm{m}) \text {, transparent }\end{array}$ \\
\hline III & $\begin{array}{l}\text { Matang } \\
\text { Mature }\end{array}$ & $\begin{array}{l}\text { Ovari kecil, warna ovari kuning, } \\
\text { tampak granula dan pembuluh darah } \\
\text { di permukaan } \\
\text { Ovary was small, yellow coloring, granules } \\
\text { and blood vessels were visible on the } \\
\text { surface }\end{array}$ & $\begin{array}{c}\text { Telur tampak buram, tidak } \\
\text { transparan, } \\
\text { ukuran diameternya } 29-52 \mu \mathrm{m} \\
\text { The eggs looked opaque, not } \\
\text { transparent } \\
\text { (diameter: } 29-52 \mu \mathrm{m} \text { ) }\end{array}$ \\
\hline IV & $\begin{array}{l}\text { Matang dan } \\
\text { siap memijah } \\
\text { Ripe and } \\
\text { running }\end{array}$ & $\begin{array}{l}\text { Ovari } 2 / 3 \text { sampai penuh dalam rongga } \\
\text { badan, warna orange-merah muda, } \\
\text { pembuluh darah di permukaan } \\
\text { Ovary had covered } 2 / 3 \text { of body cavity, } \\
\text { orangepink coloring, the blood vessels } \\
\text { were visible on the surface }\end{array}$ & $\begin{array}{l}\text { Telur matang, semi transparan, } \\
\text { ukuran diameternya } 45-70 \mu \mathrm{m} \\
\text { Mature eggs, semi-transparent, } \\
\text { (diameter: } 45-70 \mu \mathrm{m} \text { ) }\end{array}$ \\
\hline V & $\begin{array}{l}\text { Memijah } \\
\text { Spent }\end{array}$ & $\begin{array}{l}\text { Ovari } 2 / 3 \text { sampai penuh dalam rongga } \\
\text { badan, warna orange-merah muda, } \\
\text { pembuluh darah di permukaan } \\
\text { Ovary had covered } 2 / 3 \text { of body cavity, } \\
\text { orange-pink coloring, the blood vessels } \\
\text { were visible on the surface }\end{array}$ & $\begin{array}{l}\text { Telur masak semi transparan, } \\
\text { ukuran diameternya } 51-93 \mu \mathrm{m} \\
\text { Mature eggs, semi-transparent, } \\
\text { (diameter: } 51-93 \mu \mathrm{m} \text { ) }\end{array}$ \\
\hline
\end{tabular}

Dari data yang terkoleksi dapat juga diukur hubungan panjang-bobot terhadap fekunditas dan indeks kematangan gonad (IKG) ikan lalawak dengan menggunakan rumus sebagai berikut:

$$
F=\left(\frac{G}{g}\right) \times X
$$

di mana: $F=$ fekunditas

$\mathrm{G}=$ bobot gonad $(\mathrm{g})$

$g=$ bobot gonad contoh $(g)$

$\mathrm{X}=$ jumlah telur contoh (butir)

Untuk mengetahui keeratan antara jumlah fekunditas dengan panjang-bobot dan bobot gonad dengan menggunakan rumus (Effendie, 1997):

$$
F=a L^{b} ; F=a B^{b}
$$

$$
\begin{aligned}
\text { di mana: } \mathrm{F} & =\text { fekunditas total (butir) } \\
\mathrm{L} & =\text { panjang badan }(\mathrm{mm}) \\
\mathrm{B} & =\text { bobot badan }(\mathrm{g}) \\
\mathrm{a} \text { dan } \mathrm{b} & =\text { konstanta }
\end{aligned}
$$

Nilai indeks kematangan gonad (IKG) dihitung menggunakan rumus (Effendie, 1997):

$$
I K G=\frac{B g}{B t} \times 100
$$

\footnotetext{
di mana: IKG = indeks kematangan gonad $(\%$

$\mathrm{Bg}=$ bobot gonad $(\mathrm{g})$

$\mathrm{Bt}=$ bobot badan $(\mathrm{g})$
} 
Untuk mengenal gonad secara fisik lebih lanjut dilakukan juga pengamatan gonad secara visual dan mikroskopik (pengukuran diameter telur). Analisis data dilakukan dengan menggunakan program Microsoft Excel untuk membuat grafik dan memperoleh nilai $R^{2}$.

\section{HASIL DAN BAHASAN}

\section{Bioreproduksi Ikan Lalawak}

Kualitas reproduksi ikan dapat dipengaruhi oleh beberapa faktor seperti jenis ikan, ukuran ikan, umur, dan besar kecilnya diameter telur. Berdasarkan hasil koleksi data penelitian diketahui bahwa kondisi ikanikan sampel berada dalam fase tingkat kematangan gonad yang telah masak, baik ikan jantan maupun ikan betina. Dari hasil pembedahan ikan betina diperoleh data fekunditas berkisar 1.920-2.236 butir/g bobot gonad (Tabel 2) dan 83-352 butir/g total bobot badan induk. Berdasarkan mikroskopis telur (Gambar 1) dari kelima ikan sampel tersebut diketahui bahwa inti telah terbentuk dan sebagian telah berada di pinggir, dan jika dibandingkan hasil pengukuran diameter telur dengan Tabel 1 maka sampel ikan lalawak yang digunakan berada pada TKG III-IV.

Hasil tersebut menunjukkan bahwa besarnya bobot gonad dan fekunditas cenderung dipengaruhi oleh bobot dan panjang ikan. Effendie (2002) menyatakan bahwa variasi jumlah telur ikan dapat disebabkan karena adanya variasi ukuran ikan. Nilai fekunditas spesies ikan dipengaruhi oleh ukuran panjang total dan bobot badan (Sukandi, 2001). Perkembangan gonad dan fekunditas sangat dipengaruhi oleh nutrisi induk (Bromage, 1995). Akan tetapi, pada kenyataannya dari data penelitian menunjukkan bahwa tidak setiap penambahan panjang dan bobot badan diiringi kenaikan bobot gonad dan jumlah fekunditas. Hal ini diduga karena sampel ikan tidak berasal dari ukuran dan umur yang sama, semakin tua umur ikan maka semakin berkurang tingkat kesuburan alat reproduksinya dan meningkatnya diameter telur pada ikan tua akan menurunkan jumlah fekunditas ikan tersebut. Effendie (2002) menjelaskan bahwa ikan mas akan menunjukkan penambahan jumlah telur yang cepat pada umur-umur muda dan kemudian akan diikuti dengan penambahan yang semakin berkurang dan terus menurun mencapai keadaan yang tetap. Ikanikan muda yang pertama kali memijah tentunya juga akan memiliki jumlah fekunditas yang lebih sedikit dibandingkan dengan ikan-ikan yang telah pernah memijah sebelumnya.

Hasil pengamatan telur dan pengukuran diameter telur kelima ikan sampel, diperoleh informasi bahwa ikan lalawak memiliki telur berwarna hijau keabuabuan. Berdasarkan pengamatan visual, ikan lalawak memiliki gonad yang bercabang dua (Gambar 2). Bagian anterior sampai bagian posterior tiap cabang gonad tersebut memiliki ukuran dan bentuk telur yang seragam. Namun masing-masing cabang memiliki tingkat kematangan gonad yang berbeda, sehingga ikan lalawak tergolong ikan yang memijah secara parsial (partial spawner).

Hasil pengamatan menunjukkan bahwa sebaran rata-rata diameter telur dengan simpangan baku yang sangat kecil (Tabel 3), dari ukuran bobot induk betina 85,32-264,8g (Tabel 2). Jika melihat dari rata-rata diameter telur, ikan lalawak memiliki ukuran telur yang kecil namun kuantitasnya tinggi. Kondisi ini sesuai dengan pernyataan Tang \& Affandi (2001) yang menyatakan bahwa diameter telur berhubungan dengan bobot gonad dan fekunditas ikan.

Tang \& Affandi (2004) menjelaskan berbagai tahap kematangan gonad sampai dengan kematangan akhir (final maturation) dari kematangan sperma atau ovum, di mana ukuran ikan pada saat pertama kali matang gonad berkaitan dengan pertumbuhan ikan. Faktor lingkungan yang memengaruhinya yaitu suhu,
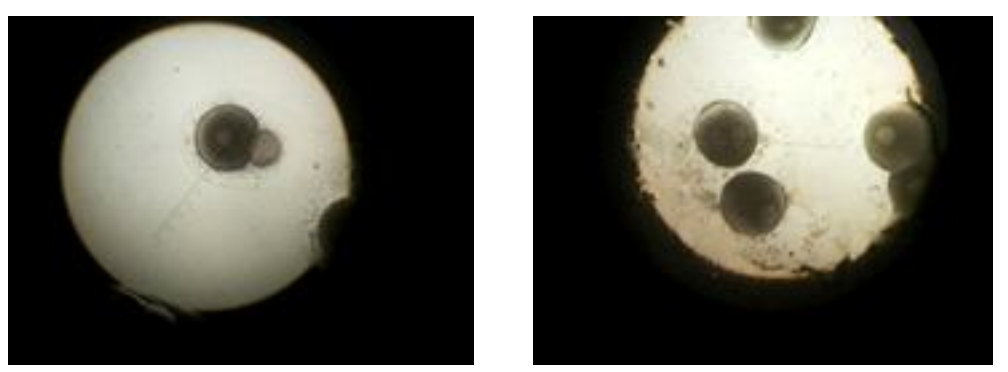

Gambar 1. Telur ikan lalawak (Barbonymus balleroides) pada TKG III dan IV pada perbesaran $4 \times 10$

Figure 1. Eggs of lalawak (Barbonymus balleroides) at maturity level of III and IV with $4 \times 10$ magnification 
Tabel 2. Biologi reproduksi ikan lalawak (Barbonymus balleroides) dari beberapa ukuran induk Table 2. Reproductive biology of lalawak (Barbonymus balleroides) from several size of adult females

\begin{tabular}{cccccc}
\hline $\begin{array}{c}\text { Sampel ke- } \\
\text { Number of sample }\end{array}$ & $\begin{array}{c}\text { Bobot badan } \\
\text { Body weight } \mathbf{( g )}\end{array}$ & $\begin{array}{c}\text { Panjang total } \\
\text { Total length }(\mathbf{m m})\end{array}$ & $\begin{array}{c}\text { Bobot gonad } \\
\text { Gonad weight }(\mathbf{g})\end{array}$ & $\begin{array}{c}\text { Fekunditas (butir) } \\
\text { Fecundity (eggs) }\end{array}$ & $\begin{array}{c}\text { IKG } \\
\text { GSI (\%) }\end{array}$ \\
\hline 1 & 85.32 & 201 & 6.57 & 14,520 & 7.70 \\
2 & 98.93 & 203 & 3.69 & 8,251 & 3.73 \\
3 & 188.5 & 236 & 34.6 & 66,432 & 18.36 \\
4 & 194 & 234 & 20.8 & 44,138 & 10.72 \\
5 & 264.8 & 256 & 10.5 & 22,281 & 3.97 \\
\hline
\end{tabular}

makanan, dan hormon. Fekunditas pada spesies yang sama dapat dipengaruhi oleh ukuran badan, umur, lingkungan, dan diameter telur (Unus \& Omar, 2010). Metabolisme optimal untuk perkembangan gonad terjadi pada saat proses reproduksi, sehingga berkorelasi dengan penambahan bobot gonad pada ikan betina 10\%25\% sedangkan pada jantan 5\%15\% (Effendie, 2002). Meretsky et al. (2000) mengatakan bahwa perubahan bobot ikan dapat dihasilkan dari perubahan pakan dan alokasi energi untuk tumbuh dan reproduksi, yang mengakibatkan bobot ikan berbeda walaupun panjangnya sama. Pada saat perkembangan kematangan gonad, semua proses metabolisme dalam badan ikan terkonsentrasi pada perkembangan gonad. Menurut Biswas (1993), perubahan struktur gonad dapat digunakan untuk menentukan tingkat kematangan gonad. Gonad yang berkembang secara visual mudah diamati karena gonad akan berkorelasi dengan perkembangan telur dan sperma.

Catatan terhadap tingkat kematangan gonad sangat penting diketahui. Hal ini berguna untuk mengetahui ikan-ikan yang telah matang gonad. Dari data penelitian ini, hasil penghitungan IKG ikan Ialawak berkisar 3,73\%18,36\% Angka ini menggambarkan bahwa saat pengambilan sampel ikan lalawak berada dalam tahap maturasi atau masa pemijahan. Menurut Gafar \& Utomo (2006), ikan Barbodes schwanenfeldii memijah jika IKG 3\%4\% Nilai ini dapat dijadikan pedoman untuk ikan lalawak. Kondisi ini didukung dengan pendapat Muslim (2007) bahwa pada umumnya ikan-ikan perairan umum (termasuk sungai, rawa, lebak lebung, dan sebagainya) memasuki musim penghujan mulai melakukan aktivitas pemijahan.

Indeks kematangan gonad merupakan suatu metode kuantitatif untuk mengetahui tingkat kematangan yang terjadi pada gonad. Pengamatan kematangan gonad dapat dilakukan dengan berbagai cara, antara lain dengan melihat morfologi gonad secara visual. Pengamatan morfologi gonad pada ikan betina berupa bentuk ovarium, besar-kecilnya ovarium, pengisian ovarium dalam rongga tubuh, warna ovarium, halus tidaknya ovarium, ukuran telur dalam ovarium secara umum, kejelasan bentuk dan warna telur dengan bagian-bagiannya, ukuran (garis tengah) telur, serta warna telur dalam keadaan segar (Effendie, 2002).
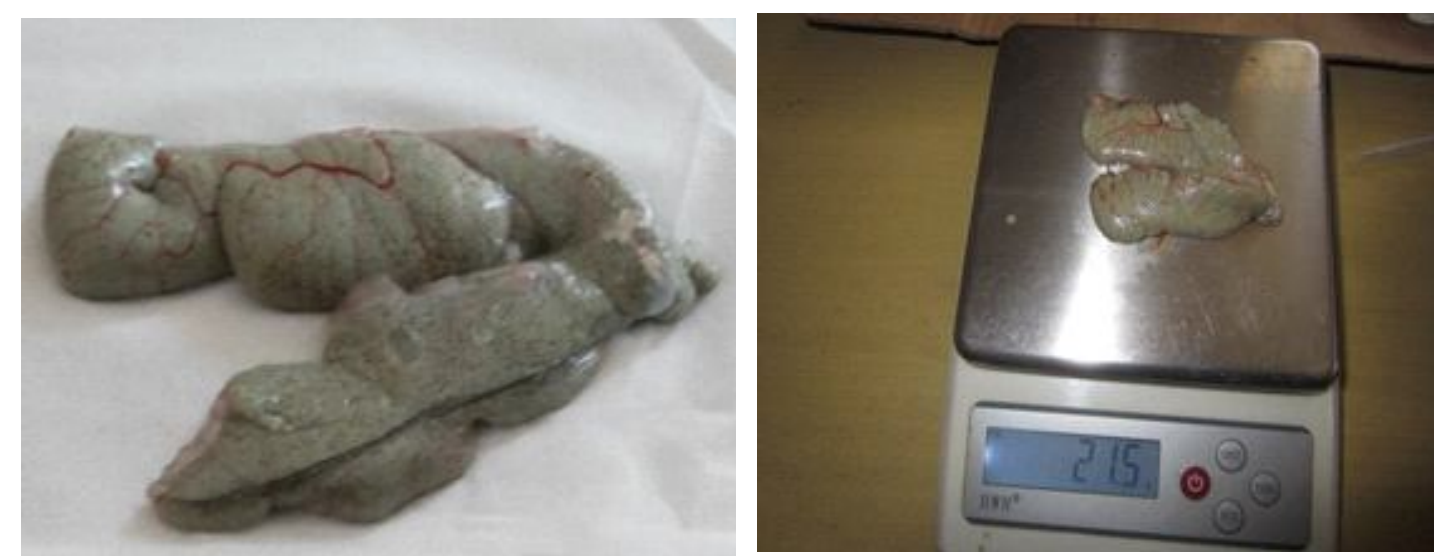

Gambar 2. Gonad betina ikan lalawak (Barbonymus balleroides)

Figure 2. Female gonad of lalawak (Barbonymus balleroides) 
Tabel 3. Pengamatan telur ikan lalawak (Barbonymus balleroides) berdasarkan visual dan makroskopis dari lima induk yang matang gonad

Table 3. Observations of lalawak (Barbonymus balleroides) eggs based on visual and macroscopic from five mature female gonads

\begin{tabular}{|c|c|c|c|c|}
\hline $\begin{array}{l}\text { Sampel } \\
\text { Samples }\end{array}$ & $\begin{array}{c}\text { Diameter telur } \\
\text { Eggs diameter }(\mathrm{mm})\end{array}$ & $\begin{array}{l}\text { Bentuk ovarium } \\
\text { Ovarian form }\end{array}$ & $\begin{array}{l}\text { Bentuk telur } \\
\text { Eggs shape }\end{array}$ & $\begin{array}{l}\text { Warna tel ur } \\
\text { Eggs colour }\end{array}$ \\
\hline 1 & $0.869 \pm 0.07$ & $\begin{array}{l}\text { Permukaan ovarium } \\
\text { bergelombang } \\
\text { Wavy ovarian surface }\end{array}$ & $\begin{array}{l}\text { Bulatan telur terlihat jelas } \\
\text { Rounded eggs clearly visible }\end{array}$ & $\begin{array}{l}\text { Hijau keabu-abuan } \\
\text { Sage-green }\end{array}$ \\
\hline 2 & $0.868 \pm 0.07$ & $\begin{array}{l}\text { Pembuluh darah terlihat } \\
\text { di permukaan } \\
\text { Blood vessels were visible on } \\
\text { the surface }\end{array}$ & $\begin{array}{l}\text { Semi transparan } \\
\text { Semi transparent }\end{array}$ & $\begin{array}{l}\text { Hijau keabu-abuan } \\
\text { Sage-green }\end{array}$ \\
\hline 3 & $1.096 \pm 0.06$ & $\begin{array}{l}\text { Jika diraba ovarium terasa } \\
\text { lebih lembek } \\
\text { Ovary felt softer if it touched }\end{array}$ & $\begin{array}{c}\text { Jika dikeluarkan dari ovarium } \\
\text { sudah terpisah satu dengan } \\
\text { yang lainnya } \\
\text { If eggs removed from the ovaries, } \\
\text { it have been separated from each } \\
\text { other }\end{array}$ & $\begin{array}{l}\text { Hijau keabu-abuan } \\
\text { Sage-green }\end{array}$ \\
\hline 4 & $1.01 \pm 0.05$ & $\begin{array}{l}\text { Bagian posterior lebih } \\
\text { lebar dibanding anterior } \\
\text { Wider posterior part } \\
\text { compared to anterior part }\end{array}$ & $\begin{array}{c}\text { Telur terlihat bersih (tidak } \\
\text { terlihat lemak yang menempel } \\
\text { pada dinding telur } \\
\text { The eggs look clean (fat were not } \\
\text { attached around the eggs) }\end{array}$ & $\begin{array}{l}\text { Hijau keabu-abuan } \\
\text { Sage-green }\end{array}$ \\
\hline 5 & $1.10 \pm 0.05$ & $\begin{array}{c}\text { Membentang sebesar } 2 / 3 \\
\text { bagian di dalam rongga } \\
\text { tubuh dari arah posterior } \\
\text { perut ke anterior } \\
\text { Ovary was stretched about } \\
\text { 2/3 part of body cavity from } \\
\text { abdominal posterior to } \\
\text { anterior }\end{array}$ & $\begin{array}{l}\text { Jika diberi larutan sera. inti } \\
\text { terlihat berada di pinggir } \\
\text { If sera solution was given to the } \\
\text { eggs, the core position will be } \\
\text { looked at the edge }\end{array}$ & $\begin{array}{l}\text { Hijau keabu-abuan } \\
\text { Sage-green }\end{array}$ \\
\hline
\end{tabular}

\section{Hubungan Panjang-Bobot Terhadap Fekunditas}

Salah satu cara untuk mengetahui produktivitas suatu jenis ikan dapat melalui pengamatan hubungan bobot terhadap fekunditas maupun terhadap panjang badan. Menurut Schneider et al. (2000), jenis kelamin dan perkembangan gonad juga memberikan variasi hubungan panjang. Semakin tinggi jumlah fekunditas maka semakin besar pula harapan untuk memperoleh produksi yang lebih tinggi dan semakin besar peluang untuk berhasil dalam dunia usaha. Ikan lalawak merupakan salah satu ikan yang memiliki fekunditas yang cukup tinggi. Jumlah fekunditas ikan erat kaitannya dengan bobot badan ikan.

Berdasarkan hasil penelitian ini, hubungan antara bobot badan dengan bobot gonad ikan lalawak digambarkan dengan persamaan linear $y=5,829 \ln (x)$ $+0,691(r=0,874)$, yang memiliki nilai korelasi yang lebih tinggi jika dibandingkan dengan hubungan panjang badan terhadap bobot gonad $(y=28,52 \ln (x)$ - 38,10; $r=0,7487$ ). Kondisi ini dapat menjadi acuan atau pedoman dalam menetapkan metode untuk menentukan jumlah fekunditas suatu spesies ikan dalam satu spesies yang sama. Effendie (2002) menjelaskan bahwa fekunditas mutlak sering dihubungkan dengan bobot ikan, sebab bobot ikan lebih mendekati kondisi ikan tersebut daripada panjang badan. Hasil penghitungan bobot-fekunditas diperoleh nilai determinan $\left(R^{2}\right) 0,9109$. Nilai ini menunjukkan bahwa terdapat 91,09\%hubungan antara bo bot badan ikan dengan fekunditas, sedangkan antara panjang ikan terhadap fekunditas hanya $79,87 \%$ 


\section{KESIMPULAN}

Berdasarkan pengamatan visual, ikan lalawak memiliki gonad yang bercabang dua. Bagian anterior sampai bagian posterior tiap cabang gonad tersebut memiliki ukuran dan bentuk telur yang seragam. Namun masing-masing cabang memiliki tingkat kematangan gonad yang berbeda, sehingga ikan lalawak tergolong ikan yang memijah secara parsial (partial spawner). Pada ikan lalawak, hubungan bobot badan dengan fekunditas lebih erat dibandingkan dengan hubungan panjang badan terhadap fekunditas, sehingga untuk menentukan produktivitas ikan lalawak sebaiknya berpedoman pada bobot badan daripada panjang badan ikan.

\section{UCAPAN TERIMA KASIH}

Pada kesempatan ini penulis menyampaikan ucapan terima kasih yang sebesar-besarnya kepada saudara Sudarmaji dan Heppy Aprilistianto selaku teknisi lapangan dan Mahasiswa/i PKL yang telah banyak membantu dalam pelaksanaan kegiatan ini sampai selesai. Penelitian ini dibiayai Anggaran DIPA Tahun 2015.

\section{DAFTAR ACUAN}

Alavi, S.M.H., Rodina, M., Policar, T., \& Linhart, 0. (2009). Relationship between semen characteristics and body size in Barbus barbus L. (Teleostei : Cyprinidae) and effects of ions and osmolality on sperm motility. Comparative Biochemistryand Physiology, 153, 430-437.

Biswas, S.P. (1993). Manual of methods in fish biology. South Asian Publishers Pvt Ltd. New Delhi.

Bromage, N. (1995). Broodstock management and seed quality general considerations. In Bromage, N.R., \& Roberts, R.J. (Eds.). Broodstock management and egg and larval quality. University Press, Cambridge. UK, p. 1-24.

Effendie, M.I. (1997). Biologi perikanan. Yayasan Pustaka Nusantara. Jogjakarta, $112 \mathrm{hlm}$.

Effendie, M.I. (2002). Biologi perikanan. Yayasan Pustaka Nusantara. Jogjakarta, $112 \mathrm{hlm}$.

Gafar, A.K., \& Utomo, A.D. (2006). Ikan lampam (Barbodes schwanenfeldii). Balai Riset Perikanan Perairan Umum.

Luvi, D.M.(2007). Aspek reproduksi dan kebiasaan makanan ikan lalawak (Barbodes balleroides) di Sungai Cimanuk, Sumedang, Jawa Barat. Skripsi. Institut Pertanian Bogor. Bogor, $64 \mathrm{hlm}$.

Meretsky, V.J., Valdez, R.A., Douglas, M.E., Brouder, M.J., Gorman, O.T., \& Marsh, P.C. (2000).
Spatiotemporal variation in length-weight relationships of endangered humpback chub: implications for conservation and management. Transactions of the American Fisheries Society 129, 419-428.

Muslim. (2007). Tingkat perkembangan gonad (TKG) ikan gabus (Channa striatus Blkr.) di sekitar Sungai Kelekar. Agria, 3, 25-27.

Schneider, J.C., Laarman, P.C., \& Gowing, H. (2000). Length-weight relationship. Manual of fisheries survey methods II. With periodic updates. Michigan Department of Natural Resources, Fisheries Special Report 25. Ann Arbor.

Setiawan, B. (2007). Biologi reproduksi dan kebiasaan makan ikan lampam (Barbonymus schwanenfeldii) di Sungai Musi, Sumatera Selatan. Skripsi. Institut Pertanian Bogor. Bogor, $117 \mathrm{hlm}$.

Siregar, S.(1991). Induksi ovulasi ikan kapiek (Puntius schwanefeldi Bleeker) dengan ekstrak hipofisa (EH) dan HCG (Hormon Chorionic Gonadotropin). Unri Press. Pekanbaru.

Sulistiono, Jannah, M.R., \& Ernawati, Y. (2001). Reproduksi ikan belanak (Mugil dussumieri) di perairan Ujung Pangkah, Jawa Timur. Jurnal Iktiologi Indonesia, 1(2), 31-37.

Sukandi. (2001). Biologi reproduksi dan pengendalian dalam upaya pembenihan ikan baung (Mystus nemurus C.) dari perairan sungai Kampar Riau. Disertasi. Institut Pertanian Bogor. Bogor.

Tang, U.M., \& Affandi, R. (2001). Biologi reproduksi ikan. Pusat Penelitian Kawasan Pantai dan Perairan. Universitas Riau. Pekanbaru, $153 \mathrm{hlm}$.

Tang, U.M., \& Affandi, R. (2004). Biologi reproduksi ikan. Unri Press. Pekanbaru.

Unus, F., \& Omar, S.B.A. (2010). Analisa fekunditas dan diameter ikan malalugis biru (Decapterus macarellus Cuvier, 1833) di perairan Kabupaten Banggai Kepulauan, Provinsi Sulawasi Tengah. Torani (Jurnal IImu Kelautan dan Perikanan), 20, 3743.

Wahyudewantoro, G., \& Haryono. (2013). Hubungan panjang berat dan faktor kondisi ikan belanak Liza subviridis di perairan Taman Nasional Ujung Kulon, Pandeglang, Banten. Bionatura-Jurnal IImu-ilmu Hayati dan Fisik, 15(3), 175-178.

Yulfiperius, R., Mozes, Toelihere, Affandi, R., \& Sjafei, D.S. (2004). Pengaruh alkalinitas terhadap kelangsungan hidup dan pertumbuhan ikan lalawak Barbodes balleroides. Jurnal Iktiologi Indonesia, 4, 1-5. 